\title{
Against the Grain
}

Volume 16 | Issue 2

Article 49

April 2004

\section{Adventures in Librarianship -- Best of Breed}

Ned Kraft

U.S. Department of State, kraftno@state.gov

Follow this and additional works at: https://docs.lib.purdue.edu/atg

Part of the Library and Information Science Commons

\section{Recommended Citation}

Kraft, Ned (2004) "Adventures in Librarianship -- Best of Breed," Against the Grain: Vol. 16: Iss. 2, Article 49. DOI: https://doi.org/10.7771/2380-176X.4327 


\section{Adventures in Librarianship - Best of Breed}

by Ned Kraft (Ralph J. Bunche Library, U.S. Department of State) <kraftno@state.gov>

Randy Wigs: Welcome. Welcome. Welcome to the 21st annual Bowker Best of Breed show, coming to you live from Madison Square Garden in New York City. I think we're in for a very exciting afternoon, wouldn't you agree, Sandy?

Sandy Billow: I certainly would, Randy. We're covering one of the most interesting breeds today: the Librarians. And, Randy, I say "interesting" because of the breed's long history, the temperaments inherent in each variety of Librarian, and their wide range of coloration.

Randy: Well put, Sandy. Although many have predicted that the Librarian breed would go the way of the Fish Mongers and the longforgotten Blacksmiths, Librarians appear to be as popular as ever.

Sandy: That's right. And our first example, the ever-popular Reference Librarian, is trotting into the ring right now. This brown-haired specimen is "Sue" and she's sponsored by Ellsworth Public in Indiana. Notice the bounce in her step, Randy. Just magnificent. And that smiling, open expression...

Randy: She's eager to please, that's for certain; and the judges always love that. The Reference variety always does well here. Did you know that the Reference was bred by ancient Nordic tribes for loyalty and herding caribou?

Sandy: I did not know that, Randy. I guess that's what makes them such good companions for children and seniors. Next up is the rare Preservation Librarian.

This breed is the result of crossbreeding standard Librarians with Archivists in the early 1940's. Not as popular here as it
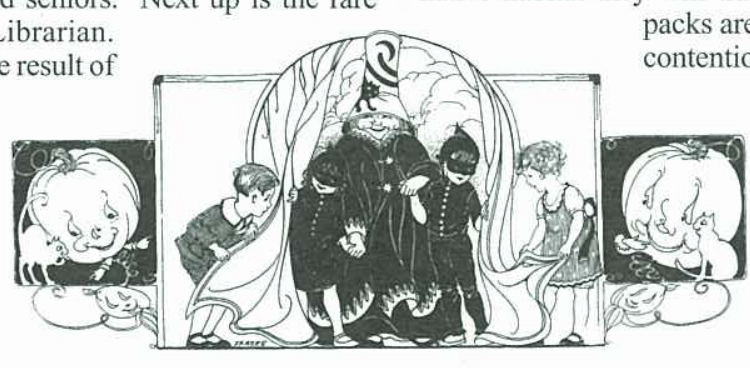

is in Europe, the Preservation Librarian tends to be solitary, not a pack Librarian, with a coarse mane and largish feet. This one is "Gustav" from Darkmound University.

Randy: Oh, he slipped! What a shame. That's going to hurt his chances here, Sandy. For all their intelligence, the Preservation Librarians have never been graceful in the ring.

Sandy: A real disappointment. Did you hear the gasp from the audience? Let's see what "Ned" the Acquisitions Librarian can do. He's moving quickly around the ring. Almost too quickly, don't you think?

Randy: Well, remember that this variety is known for its keen, almost goofy sense of humor, its large snout, anxious energy, and commanding voice. Legend says this variety was developed by Native Alaskans specifically to negotiate for beads and host potlatches.

Sandy: Certainly the most entertaining of the Librarian breed, Randy, but not a handsome lot. The males tend toward early baldness and the females are often long in the torso.

Randy: Next is the Cataloging Librarian, often simply called "the Cataloger." Much has been said about this variety. Some of it true. Some of it not. It is, however, the most serious of the breed, known for its focus. Australian farmers still use Catalogers for locking up the out-buildings and preventing children from tracking mud into the house. Although in their native habitat they will travel in packs, those packs are often dangerously ontentious.

S a n d y : That's right, Randy. This one is "Estrella" from Altamont School District in California. See how slowly and deliberately she moves around the ring? The Catalogers mane evolved to increase that focus. With those short bangs and long, limp hair around the ears, when their heads tilt to read a book, the limp hair falls forward to form natural blinders, blocking out all distraction. That's years of meticulous breeding, Randy. Her father was a champion in this very arena.

Randy: Fascinating. Oh, how about this next one? What a beauty! This is the newest and most popular variety: the Bibliothécaire Des Resources Électroniques, or simply BDRE. Developed in France in the early 1980's, the variety has thrived here in the US.

Sandy: This blonde specimen is "Bruce" all the way from Minerva College. Bruce comes from a strong lineage of.... Oh my goodness! He walked right into the judge!

Randy: I hate to say it, Sandy, but his chances are zero at this point. As dexterous as the BDRE is, they are very distractible, very short attention spans. This one just started looking into the floodlights and Wham!

Sandy: Well, there's always next year for Bruce. The judge is circling the ring now. It's the moment of truth. He's calling each Librarian forward a few steps, asking them to turn. He's checking Estrella's teeth one last time.

Randy: He's stepping back, scanning the ring. And... He's pointing to Sue, the Reference Librarian!

Sandy: No surprise there, Randy. Her performance was flawless. Her pedigree is perfect. And the crowd loved her. As she takes her victory trot around the ring, this has been Sandy Billow...

Randy: ... and Randy Wigs with the 21st annual Bowker Best of Breed show live from Madison Square Garden. Stay tuned next as the Librarian channel brings you a new episode of Detroit Library Cops.

\section{Rumors \\ from page 16}

As we go to press, Ramune Kubilius sends word from a post in MEDREF-L. Forty-eight not-for-profit publishers and medical societies - including the American Academy of Pediatrics, American Cancer Society, the American Diabetes Association, Society of Surgical Oncology, The Botanical Society of America, The Endocrine Society, The Rockefeller University Press and others have created and signed a document called the Washington DC Principles for Free Access to Science. This document announces their commitment to providing free access and wide dissemination of published research findings.

http://www.dcprinciples.org/
See the article in the March 23, 2004 InfoToday NewsBreaks, "Sci-Tech Not-ForProfit Publishers Commit to Limited Open Access" by Barbara Quint.

http://www.infotoday.com/newsbreaks/ nb040322-2.shtml

Institute of Physics Publishing with the awesome Managing Director Jerry Cowhig $<$ jerry.cowhig@iop.org > has acquired 50\% of Turpion Ltd from the Royal Society of Chemistry. The other $50 \%$ shareholder is Pion Ltd. The change in ownership is effective from January 1, 2004. Turpion represents an effective cooperation between the Russian Academy of Sciences and learned societies in the West to make available English translations of leading Russian journals in physics, math, and chemistry. It was founded in 1990 by the RSC and Pion. The RSC will maintain its association with the chemistry journals, and the London Mathematical Society with the math journals. No immediate changes are projected. IOP already has two editorial offices in Russia. It also has editorial offices in China and Japan, and publishing collaborations with the Chinese Physical Society and many other international scientific societies.

www.rsc.org

www.iop.org

www.turpion.org

And, YES, the 2000 Charleston Conference Proceedings, Is Bigger Better? ARE available for $\$ 25.00$ prepaid. To order a copy contact yours truly $<$ kstrauch@comcast.net $>$ or Toni Nix at Just Right Group, LLC. <justwrite@lowcountry.com>. Purchase orders can be faxed to 843-835-5892.

continued on page 91 